\title{
Analisis Buku Biologi SMA Kelas X Materi Kingdom Animalia Berdasarkan Literasi Sains Se-Kabupaten Deli Serdang
}

\author{
Fitriana Siregar $^{1 *}$, Hasruddin $^{2}$, Ely Djulia ${ }^{2}$ \\ ${ }^{1}$ Guru di SMK Taman Siswa cabang Lubuk Pakam, *E-mail: ficusbenjamina5@gmail.com \\ ${ }^{2}$ Program Studi Pendidikan Biologi Pascasarjana, Universitas Negeri Medan, Sumatera Utara, Indonesia
}

\begin{abstract}
The aimed of this research was to know level of scientific literacy of Animalia Kingdom on senior high school biology book at grade $\mathrm{X}$ in Deliserdang. The method of this research was descriptive quantitative by analyzing 7 the Biology Books from different publisher for grade $\mathrm{X}$ on animalia Kingdom topic. Books was assessed by researcher. Researcher assessed Animalia Kingdom on Senior High School biology books at grade X in Deliserdang based of scale questioner Animalia Kingdom on Senior High School biology books grade $\mathrm{X}$ with science of the body of knowladge, science as a way of investigating, science as a way of thinking, and interaction science, technology, and society. Result of this research shown that persentage of thema science as a body of knowledge was $21,86 \%$, persentage of science as a way of investigating was $15,27 \%$, persentage of science as a way of thinking was $11,91 \%$, and persentage of interaction science, technology, and society was $10,36 \%$. It can be concluded that percentage of scientific literacy of Animalia Kingdom on Senior High School biology books at grade X in Deliserdang was 59,42\% (not yet scientific literacy).
\end{abstract}

Key Word: Biology book, Kingdom Animalia, Science literacy

\section{PENDAHULUAN}

Studi Programme Internationale for Student Assesment (PISA) tahun 2012 menunjukkan bahwa literasi sains negara Indonesia terdapat pada peringkat ke 64 dari 65 negara dengan skor rata-rata 382 sedangkan rata-rata skor rata-rata internasional adalah 500 (Balitbang Kemdikbud, 2015). Hal ini berarti kemampuan rata-rata siswa Indonesia dalam menggunakan pengetahuan dan mengidentifikasi masalah untuk memahami fakta-fakta dan membuat keputusan tentang alam serta perubahan yang terjadi pada lingkungan masih rendah jika dibandingkan dengan negara lain.

Tinggi rendahnya literasi sains siswa dipengaruhi secara positif oleh sikap siswa terhadap sains dan latar belakang pendidikan orang tua. Literasi sains berkorelasi negatif dengan strategi problem based learning, penggunaan fenomena untuk mengilustrasikan topik, dan penyelidikan laboratorium, tetapi literasi sains berkorelasi positif dengan strategi kooperatif (peer teaching), dan pemodelan. Tinggi rendahnya sikap siswa terhadap sains dipengaruhi secara positif oleh pekerjaan yang diinginkan siswa, kegiatan belajar mengajar di kelas, latar belakang pendidikan orang tua, dan banyaknya waktu yang digunakan siswa untuk belajar sains. Kepercayaan diri dan motovasi belajar siswa berkolerasi positif dengan literasi sains. Semakin besar kepercayaan diri dan motivasi belajar sains, semakin besar literasi sains yang dicapai oleh siswa. (Ekohariadi, 2009).

Menurut Glynn dan Muth (1994) salah satu langkah untuk membantu siswa dalam mencapai literasi sains adalah dengan menjamin bahwa kurikulum yang digunakan di sekolah adalah kurikulum yang mendukung upaya siswa dalam mempelajari sains secara bermakna. Dalam kurikulum yang berliterasi sains, membaca dan menulis dapat menjadi sarana untuk pembelajaran sains secara bermakna.

Buku materi adalah bagian dari proses pembelajaran yang dilakukan guru dan siswa di sekolah. Buku materi juga merupakan sarana penunjang pemahaman siswa terhadap suatu materi, karena bisa dibaca baik disekolah maupun dirumah. Sehingga membantu tugas guru sebagai pendidik.

Namun yang terjadi adalah banyak siswa yang mengalami miskonsepsi 
terhadap materi pembelajaran biologi, meskipun mereka memiliki buku materi. Contohnya yang terjadi terhadap siswa kelas X-IPA-4 SMAN 26 Jakarta dan siswa SMA se-Kota Medan, mengalami miskonsepsi di setiap subkonsep pada Klasifikasi Dunia Hewan (Septiana, 2014; Panggabean, 2011). Panggabean (2011) menganalisis bahwa siswa paling sering mengalami miskonsepsi pada konsep Porifera, Coelenterata, Platyhelminthes, Nemathelminthes, Annelida, Mollusca, Arthropoda, Echinodermata, dan Coelenterata.

Hal ini terjadi karena buku biologi yang digunakan sebagai pegangan guru maupun siswa memuat begitu banyak konsep-konsep yang terkadang sulit untuk dimengerti oleh siswa. Mela (2010) menyatakan bahwa tugas guru bukan hanya menyampaikan materi pembelajaran tetapi juga memilih material pembelajaran yaitu buku, dan dalam melakukan pembelajaran harus mengikuti atau memperhatikan pada tujuan siswa berkaitan dengan masa depan karir mereka sehingga bukan hanya mengikuti ketentuan kurikulum saja.

Jika suatu masyarakat mengetahui bagaimana saintis bekerja dan mengambil kesimpulan dan apa yang membatasi kesimpulan mereka, maka masyarakat tersebut akan memiliki lebih banyak kemungkinan untuk bertindak dengan penuh pertimbangan seperti seorang saintis dan kemungkinannya akan sangat kecil untuk menolak atau menerima sesuatu secara tidak kritis (AAAS, 1993).

Berdasarkan hasil observasi yang telah peneliti lakukan, diketahui bahwa siswa SMA Kelas X di Deliserdang belum memiliki kemampuan literasi sains. Siswa tidak dapat menjawab pertanyaanpertanyaan yang diberikan oleh peneliti yang berkaitan dengan materi kingdom animalia yang telah disesuaikan dengan soal-soal berdasarkan literasi sains. Selain itu, berdasarkan wawancara yang dilakukan kepada peneliti dengan siswa-siswa tersebut ternyata ada berbagai buku pelajaran yang digunakan di sekolah-sekolah yang ada di Deli Serdang.

Untuk tingkat literasi sains pada isi buku biologi SMA dapat diketahui dengan menganalisis empat tema atau dimensi literasi ilmiah pada isi buku yang meliputi science as a body of knowledge, science as a way of thinking, science as a way of investigasting dan science and its interaction with technology and society. (Chiapetta, et al, 1991).

\section{METODE PENELITIAN}

Sampel terdiri dari 7 buku biologi kelas $\mathrm{X}$ materi Kingdom Animalia yang beredar di Kabupaten Deliserdang. Instrumen yang digunakan berupa skala penilaian buku biologi kelas X materi Kingdom Animalia berdasarkan sains sebagai batang tubuh ilmu pengetahuan, sains sebagai proses investigasi, sains sebagai cara berfikir, dan interaksi antara sains, teknologi, dan masyarakat. Penilaian dilakukan oleh peneliti dan guru biologi SMA kabupaten Deliserdang.

Data dianalisis dengan menggunakan rumus:

$$
P=\frac{F}{N} \times 100 \%
$$

Intepretasi jawaban dikategorikan sbb:

Sangat berliterasi sains $=81,00 \%$ $100,00 \%$

Berliterasi sains $\quad=61,00 \%-80,99 \%$

Kurang berliterasi sains $=41,00 \%-$ $60,99 \%$

Tidak berliterasi sains $=<40,99 \%$

\section{HASIL DAN PEMBAHASAN}

Berdasarkandata yang diperoleh dari hasil analisis peneliti yang menilai tentang literasi sains yang terkandung dalam buku biologi SMA kelas $\mathrm{X}$ materi Kingdom Animalia yang beredar di Kabupaten Deliserdang, diperoleh gambaran dalam bentuk persen dan kategori penilaian seperti pada Tabel 3.1 dibawah ini. 
Tabel 1. Persentase skor tema literasi sains buku biologi kelas X materi Kingdom Animalia yang beredar di Deliserdang

\begin{tabular}{|c|c|c|c|c|}
\hline No & Tema & Indikator & Skor & Persentase (\%) \\
\hline \multirow[t]{4}{*}{1} & $\begin{array}{l}\text { Batangtubuh } \\
\text { ilmu }\end{array}$ & $\begin{array}{l}\text { Menyajikan fakta-fakta, konsep-konsep, } \\
\text { prinsip-prinsip, \& hukum-hukum. }\end{array}$ & 112 & 12,12 \\
\hline & pengetahuan & $\begin{array}{l}\text { Menyajikan hipotesis-hipotesis, teon- } \\
\text { teori, dan model-model. }\end{array}$ & 57 & 6,17 \\
\hline & & $\begin{array}{l}\text { Meminta siswa untuk mengingat } \\
\text { pengetahuan atau informasi }\end{array}$ & 33 & 3,57 \\
\hline & Total & & 202 & 21,86 \\
\hline \multirow[t]{6}{*}{2} & $\begin{array}{l}\text { Sains sebagai } \\
\text { proses }\end{array}$ & $\begin{array}{l}\text { Mengharuskan siswa untuk menjawab } \\
\text { pertanyaan melalui penggunaanmater }\end{array}$ & 13 & 1,41 \\
\hline & investigasi & $\begin{array}{l}\text { Mengharuskan siswa untuk menjawab } \\
\text { pertanyaanmelalui grafik-grafik, tabel- } \\
\text { tabel, dll }\end{array}$ & 41 & 4,44 \\
\hline & & $\begin{array}{l}\text { Mengharuskan siswa untuk membuat } \\
\text { kalkulasi }\end{array}$ & 12 & 1,3 \\
\hline & & $\begin{array}{l}\text { Mengharuskan siswa untuk } \\
\text { menerangkanjawaban }\end{array}$ & 12 & 1,3 \\
\hline & & $\begin{array}{l}\text { Melibatkan siswa dalam eksperimen } \\
\text { atau aktivitas berfikir. }\end{array}$ & 63 & 6,82 \\
\hline & Skor & & 141 & 15,27 \\
\hline \multirow[t]{5}{*}{3} & $\begin{array}{l}\text { Sains sebagai } \\
\text { cara berfikir. }\end{array}$ & $\begin{array}{l}\text { Menggambarkan bagaimana seorang } \\
\text { ilmuwan menemukan atau melakukan } \\
\text { eksperimen }\end{array}$ & 18 & 1,95 \\
\hline & & $\begin{array}{l}\text { Menunjulkkan perkembangan (historis) } \\
\text { dari sebuah ide }\end{array}$ & 9 & 0,97 \\
\hline & & $\begin{array}{l}\text { Menekankan sifat empiris dan } \\
\text { objektivitas ilmu sains }\end{array}$ & 17 & 1,84 \\
\hline & & $\begin{array}{l}\text { Mengilustrasikan penggunaan asumsi- } \\
\text { asumsi. }\end{array}$ & 21 & 2,27 \\
\hline & & $\begin{array}{l}\text { Menunjukkan bagaimana ilmu sains } \\
\text { berjalan dengan pertimbangan induktif } \\
\text { dan deduktif. }\end{array}$ & 13 & 1,41 \\
\hline
\end{tabular}

Berdasarkan Tabel 1 di atas dapat dilihat bahwa tema yang memiliki persentase terbanyak adalah tema sains sebagai batang tubuh ilmu pengetahuan sebanyak $21,86 \%$, kemudian sains sebagai proses investigasi sebanyak $15,27 \%$, kemudian sains sebagai cara berfikir sebanyak $12,12 \%$, dan terakhir adalah interaksi antara sains, teknologi, dan masyarakat sebanyak 10,36\%. Dan terdapat
40,4\% indikator literasi sains yang tidak terpenuhi di dalam buku biologi kelas $\mathrm{X}$ materi Kingdom Animalia yang beredar di Kabupaten Deliserdang.

Hasil analisis tema-tema literasi sains tersebut diatas yang telah dilakukan peneliti pada buku-buku biologi kelas $\mathrm{X}$ materi kingdom animalia yang beredar di kabupaten Deliserdang dapat dilihat pada gambar 1 di bawah ini. 


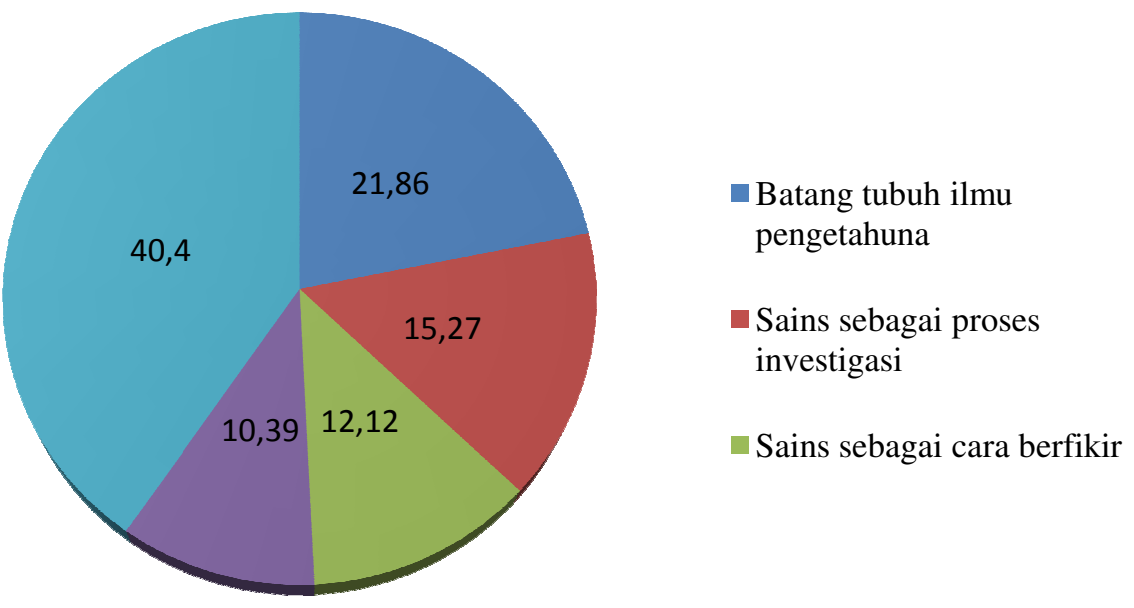

Gambar 1. Persentase setiap tema literasi sains pada buku biologi SMA Kelas X Materi Kingdom Animalia yang beredar di Kabupaten Deliserdang

Tabel 2. Persentase setiap tema literasi sains pada setiap buku biologi kelas X materi Kingdom Animalia yang dianalisis yang beredar di Deliserdang

\begin{tabular}{|c|c|c|c|c|c|c|c|c|}
\hline \multirow{2}{*}{ No } & \multirow{2}{*}{ Tema } & \multicolumn{7}{|c|}{ Penerbit Buku } \\
\hline & & 1 & 2 & 3 & 4 & 5 & 6 & 7 \\
\hline 1 & Batang tubuhilmu pengetahuan & 20,45 & 24,24 & 20,45 & 22,73 & 22,73 & 20,45 & 21,97 \\
\hline 2 & Sains sebagaiproses investigasi & 14,39 & 16,67 & 9,85 & 18,94 & 16,67 & 17,42 & 12,88 \\
\hline 3 & Sains sebagai cara berfikir & 13,64 & 11,36 & 13,64 & 12,12 & 13,64 & 11,36 & 9,09 \\
\hline 4 & $\begin{array}{l}\text { Interaksi antara sains, } \\
\text { teknoloogi, danmasyarakat }\end{array}$ & 8,33 & 11 & 8,33 & 11,36 & 15,15 & 8,33 & 9,85 \\
\hline & Total Literasi Sains & 56,82 & 63,64 & 52,27 & 65,15 & 68,18 & 57,58 & 53,79 \\
\hline & Tidak memenuhi Literasi Sains & 43,18 & 36.36 & 47,73 & 34,85 & 31,82 & 42,42 & 46,21 \\
\hline & Total & 100 & 100 & 100 & 100 & 100 & 100 & 100 \\
\hline
\end{tabular}

Berdasarkan Tabel 2. di atas terlihat bahwa ada beberapa buku yang memiliki kategori buku berliterasi sains, yaitu buku 2, buku 4, dan buku 5. Buku 5 memiliki proporsi yang paling tinggi dibandingkan dengan keenam buku yang lain. Buku yang memiliki proporsi literasi sains yang paling sedikit adalah buku buku 3 .

Data dari masing-masing buku materi berdasarkan hasil penyebaran skala penilaian yang dilakukan oleh guru-guru Biologi yang mengajar di SMA Kabupaten Deliserdang dapat dilihat pada Tabel 3.3 di bawah ini.

Keseluruhan rata-rata persentase hasil penilaian tema literasi sains pada ketujuh buku materi Kingdom Animalia pada Buku Biologi Kelas $\mathrm{X}$ yang paling banyak muncul adalah tema sains sebagai batang tubuh ilmu pengetahuan sebasar 21,86\%. Tema ini lebih menekankan pada pengetahuan informasi dari hasil produk pemikiran para ilmuwan yang meliputi fakta, konsep, prisip, hukum, teori, model dan hipotesis (Chiappetta \& Koballa, 2010).

Tema sains sebagai proses investigasi menjadi tema kedua yang banyak ditekankan dari ketujuh buku materi Kingdom Animalia yang dianalisi yaitu sebesar $15,27 \%$. Tema sains sebagai proses investigasi ini digunakan untuk memanfaatkan beberapa pendekatan untuk mengkonstruksi pengetahuan (Chiappetta dan Koballa 2010).

Dalam ketujuh buku yang dianalisis situasi yang muncul buku rata-rata adalah kegiatan praktikum seperti "membuat pupuk dari cangkang bekicot", selain itu buku juga meminta siswa untuk membuat suatu solusi seperti "meminta siswa untuk menganalisis cara mencegah infeksi cacing 
hati dan cacing pita berdasarkan gambar daur hidup cacing hati dan cacing pita.

Sains sebagai cara berpikir pada ketujuh buku memiliki nilai rata-rata sebesar 12,12\%. Dari hasil analisis menunjukkan tidak ada satu buku materi pun yang memuat tentang cara ilmuwan bereksperimen dan meminta siswa untuk mendiskusikan suatu wacana yang menggambarkan kondisi hewan saat ini.

Buku-buku tersebut menunjukkan penemuan dari seorang ilmuwan, tapi tidak menunjukkan bagaimana sampai penemuan itu ditemukan, atau proses menemukan itu terjadi misalnya penemuan tentang pergerakan lubang-lubang mulut spons yang mengatur arus air pada tubuh spons.

Tema sains dan interaksinya dengan teknologi dan masyarakat muncul paling sedikit dan tidak ditekankan pada buku biologi kelas $\mathrm{X}$ materi kingdom animalia yang beredar di Deliserdang dengan persentase sebesar 10,39\%. Tema ini berhubungan dengan dampak sains dan teknologi pada masyarakat dimana akan membantu manusia atau malah merusak lingkungan dan berdampak negatif pada manusia.

Keterlibatan guru dalam penelitian ini diperlukan karena guru biologi SMA kabupaten Deliserdang adalah pihak yang berhubungan langsung dengan buku materi biologi yang beredar di kabupaten Deliserdang. Dengan demikian diharapkan guru biologi SMA kabupaten Deliserdang dapat menseleksi buku biologi yang akan guru biologi dan siswa pergunakan saat proses pembelajaran guna membantu proses pembelajaran tersebut.

Hasil yang diperoleh adalah penilaian yang dilakukan guru dan peneliti memiliki hasil yang berbeda. Perbedaan penilaian ini bisa terjadi karena tingkat pengetahuan atau pengertian tentang literasi sains antara guru biologi SMA kabupaten Deliserdang dengan peneliti berbeda. Selain itu bisa juga dipengaruhi oleh perbedaan kepentingan antara guru biologi SMA kabupaten Deliserdang dengan peneliti sendiri.

Buku materi yang baik mampu menghubungkan setiap materi dengan penelitian ilmiah serta sains, teknologi, dan masyarakat dengan lebih menonjolkan bagaimana aspek sains diilakukan dan peran sains dalam kehidupan (Campbell, et al. 2010), serta menyebutkan karir-karir seperti menjadi peneliti, pembudidaya, desaigner poster, dll sehingga siswa mempunyai pandangan pada karir-karir tersebut.

Buku materi sains yang baik harus menggambarkan sains disetiap sisinya dengan baik dan benar. Belajar sains berkaitan dengan usaha mencari penjelasan terhadap fenomena alam. Buku materi dapat digunakan untuk meningkatkan kualitas sains siswa untuk lebih melek ilmiah. Tema literasi sains dalam buku seharusnya disajikan secara seimbang pada empat tema literasi sains tersebut yaitu sains sebagai batang tubuh pengetahuan, sains sebagai jalan berpikir, sains sebagai jalan investigasi dan sains dan interaksinya dengan teknologi dan masyarakat pada isi/materi buku. Keseimbangan keempat dimensi literasi ilmiah dalam isi/materi buku akan mengakibatkan tingkat literasi ilmiah siswa dapat meningkat yang juga dapat meningkatkan mutu pedidikan sains siswa.

\section{SIMPULAN}

Berdasarkan hasil kesimpulan diperoleh bahwa tingkat literasi sains buku biologi SMA kelas X pada materi kingdom animalia dan peranannya bagi kehidupan adalah 59,6\%, dengan tema sains sebagai batang tubuh ilmu pengetahuan sebanyak $21,86 \%$, sains sebagai proses investigasi sebanyak $15,27 \%$, sains sebagai cara berfikir sebanyak $12,12 \%$, interaksi antara sains, teknologi dan masyarakat sebanyak $10,36 \%$.

\section{DAFTAR PUSTAKA}

(AAAS) American Association for the Advancement of Science (1993)Benchmarksfor science literacy. Washington, DC. http://tinyurl.com/cbn7md8 (diakses tanggal 21 September 2015).

Balitbang Kemdikbud (2015) Survei Internasional PISA. litbang. kemdikbud.go.id/index.php. survei- 
internasional-pisa(diakses tanggal 22 September 2015)

Campbell, N.A., J.B. Reece, L.A. Urry, M.L. Cain, S.A. Waserman, P.V. Minorsky \& R.B. Jackson (2010)Biologi Edisi Kedelapan Jilid 2. Jakarta: PT. Erlangga

Chiapetta, E.L., Fillman, Sethna (1991)Procedures for Conducting Content analysis of Science Textbooks, Texas: Department of Curriculum and Instruction, Houston.

Chiappetta, E.L. dan T.R. Koballa (2010)Science Instruction in The Middle and Secondary Schools: Developing Fundamental Knowledge and Skills. United State of America: Pearson Education Inc.

Ekohariadi (2009) Faktor-Faktor yang Mempengaruhi Literasi Sains Siswa Indonesia Berusia 15 Tahun. Jurnal Pendidikan Dasar, 10(1), hlm. 28-41.
Glynn, S.M., dan K.D. Muth(1994) Reading and Writing to Learn Science: Achieving Scientific Literacy. Journal of Research in Science Teaching, 31(9), hlm. 1057-1073.

Mela, D. dan A. Supuran(2010) Textbook selection - an important factor in introducing ESP in vocational schools. a case study. Analele Universitătii din Oradea Fascicula: Ecotoxicologie, Zootehnie si Tehnologii de Industrie Alimentară, 3(1), hlm. 1514-1519.

Panggabean, H. N. S.(2011)Analisis Miskonsepsi Siswa dan Guru Biologi Tentang Materi Klasifikasi Dunia Hewan Pada SMA Se-Kecamatan Medan Helvetia. Medan: PPS Universitas Negeri Medan.

Septiana, D.(2014)Identifikasi Miskonsepsi Siswa Pada Konsep Archaebacteria dan Eubacteria Menggunakan Two-Tier Multiple Choice. Jakarta: UIN Syarif Hidayatullah. 